\title{
ARE WOMEN ENTREPRENEURS' BUSINESS PERFORMANCES INFLUENCED BY FINANCIAL RESOURCES? EMPOWERING WOMEN ENTREPRENEURS IN MALAYSIA THROUGH FINANCIAL RESOURCES POST-COVID-19 PANDEMIC
}

\author{
Kumaran Kanapathipillai ${ }^{1 i}$, \\ Subaneeswasri Narayanan², \\ Sharvena Kumaran ${ }^{3}$ \\ ${ }^{1}$ Faculty of Business and Technology, \\ UNITAR International University, \\ Tierra Crest, Jalan SS6/3, \\ Kelana Jaya, 47301 Petaling Jaya, \\ Selangor, Malaysia \\ ${ }^{2}$ Academician, \\ Independent Researcher \& Education Consultant, \\ Malaysia \\ ${ }^{3}$ Independent Researcher, \\ Online Entrepreneur, Software Engineer, \\ Malaysia
}

\begin{abstract}
:
Entrepreneurship has always been women's interest, and women have risen in the business arena. On the other hand, statistic shows that Malaysian women's participation in entrepreneurship is still minute but vital to Malaysia's economic development, as indicated by previous researchers. Additionally, the impact of the Covid-19 pandemic has caused adverse effects on women-owned businesses in Malaysia. This research aims to offer an insight into how financial capital, the amount of capital needed, and personal savings of women entrepreneurs induces business performance among women entrepreneurs in Malaysia. This study used quantitative methods to produce empirical outcomes and substantiations to answer the research questions. A total of 312 women entrepreneurs participated in this study which facilitated the findings and conclusions. The results demonstrated that financial capital, the amount of capital needed, and personal savings were statistically significant for the women entrepreneurs post Covid19. Additionally, the findings of this research will undoubtedly give confidence to the women entrepreneurs to come out of the Covid-19 shock and operate their business more remarkably as well as continue to progress and enhance their business performance taking into account the significance of financial resources.
\end{abstract}

i Correspondence: email kumar.erapintar@gmail.com frank.erapintar@gmail.com 
JEL: L20; L23

Keywords: women entrepreneurship, performance, financial capital, capital amount, personal savings

\section{Introduction}

Business-minded women in Malaysia have been on the rise, according to the Ministry of Women, Family and Community Development (Statistics on Women, Family \& Community, 2019). The contribution of women to the development of Malaysia is so crucial that it has been highlighted by the government and scholars in the field of entrepreneurship (Kanapathipillai \& Azam, 2019b). The involvement of women in the Malaysian labour force is crucial to transforming Malaysia into a developed nation from a developing nation, according to (Hassan \& Yusof, 2015). Even if the number of women entrepreneurs has been remarkably rising on an annual basis (Thuaibah et al., 2007), research concentrated on women entrepreneurs' performance in Malaysia is insufficient (Teoh \& Chong, 2007). Moreover, several researchers have conducted studies on the effect of the Covid-19 lockdown on entrepreneurs, but very little research was conducted on the struggles of women entrepreneurs during and after the uplifting of the lockdown (Mustafa et al., 2021; Kuckertz et al., 2020; Shepherd, 2020).

Additionally, the impact of the SARs-CoV-2, better known as the silent killer, has devastated many businesses and businesses owned by women (Chipfunde et al., 2021; Mahat et al., 2021; Lim, 2020). This study will fill this gap by furnishing an understanding of the impact of financial capital, amount of capital needed, and personal savings used on women entrepreneurs' business performance post-Covid-19 pandemic.

\subsection{Research Problem Statement}

Being an entrepreneur entails substantial challenges, predominantly for a women entrepreneur, whereby she has to accept all the responsibilities for business performance, subsequent earnings as well as failures (Elahi \& Malik, 2021; Azam \& Moha Asri, 2015; Udriyah et al., 2019). The probability of enhanced performance is substantially more arduous for a women entrepreneur, who has to face and overcome business difficulties besides the complications associated with operating a business in a male governed business environment (Mustafa et al., 2021; Al-Shami et al., 2019; Selvadurai, 2019; Aliyu et al., 2019; Alam et al., 2011). Still, many women have chosen to run their businesses on their own (Khursheed et al., 2021; Muhammad et al., 2020; Hisrich \& Brush, 1984). Additionally, women entrepreneurs have been traumatized by the shock of the Covid-19 pandemic and have had constraints accessing financial capital, which affected their business performance (Chipfunde et al., 2021; Welsh et al., 2018) Furthermore, (Dy \& Jayawarna, 2020; Seetharaman, 2020; Werner, 2020; Bartik et al., 2020) elucidated that the Covid-19 pandemic has affected the micro-enterprises of all entrepreneurs as well as women entrepreneurs tremendously. Therefore, women entrepreneurs have to rethink 
Kumaran Kanapathipillai, Subaneeswasri Narayanan, Sharvena Kumaran

ARE WOMEN ENTREPRENEURS' BUSINESS PERFORMANCES INFLUENCED BY

FINANCIAL RESOURCES? EMPOWERING WOMEN ENTREPRENEURS IN MALAYSIA

THROUGH FINANCIAL RESOURCES POST-COVID-19 PANDEMIC

their business strategy in order to obtain the required financial resources to maintain their business after the lockdown is lifted.

Financial capital has been the main concern for many women entrepreneurs, especially during the start-up phase of the business (Al-Shami et al., 2019; Guzman \& Kacperczyk, 2019; Kanapathipillai \& Azam, 2019a). Inadequate financial capital during the initial start-up and the development of the business have impacted the growth and performance of the women-owned businesses (Al-Shami et al., 2019; Kanapathipillai \& Azam, 2019b). Securing financial resources will make a difference in realizing the goals and the business performance of the women entrepreneurs (Al-Shami et al., 2019; Murphy et al., 1996; Watts, 2003). Moreover, inadequate capital has affected the ability of the women entrepreneur to secure further loans from the banks (Rashid \& Ratten, 2020; Storey, 1994).

Additionally, (Dzisi, et al., 2015; Tchouvakhina, 2013; Haynes \& Haynes, 1999; Coleman \& Carsky, 1996) have uncovered that women entrepreneurs were not willing to go for formal borrowing such as banks but, instead use informal financial resources such as their own personal savings and borrow from their family and friends. This causes several problems for the women entrepreneurs when it comes to returning their informal loans (Kanapathipillai \& Azam, 2019a). Further evidence by (Cole \& Wolken, 1995; Carter \& Rosa, 1996) shows that women entrepreneurs use less non-depository financial services and little trade credit.

Women entrepreneurs consistently admit facing an escalation of obstacles when securing any amount of financial capital to invest in their business. Furthermore, women entrepreneurs regularly whine that they could not undertake profitable business contracts due to underfinancing (Chipfunde, 2021; Kanapathipillai \& Azam, 2019b). Additionally, based on previous research (Carter et al., 2006) affirmed that there is an indication that women entrepreneurs are often underfinanced.

All these issues have hampered the growth of women entrepreneurs. Therefore, it is worthwhile to assess the impact of financial capital on the performance of women entrepreneurs in Malaysia.

\subsection{Research Questions}

The research questions of this study are as follows:

RQ1: Is there a statistically significant relationship between financial capital and the performance of the women entrepreneurs?

RQ2: Is there is a statistically significant relationship between large amount of capital needed and the performance of the women entrepreneurs?

RQ3: Is there a statistically significant relationship between personal savings and the performance of the women entrepreneurs?

\subsection{Research Objectives}

The research objectives of this study are as follows: 
Kumaran Kanapathipillai, Subaneeswasri Narayanan, Sharvena Kumaran

ARE WOMEN ENTREPRENEURS' BUSINESS PERFORMANCES INFLUENCED BY

FINANCIAL RESOURCES? EMPOWERING WOMEN ENTREPRENEURS IN MALAYSIA

THROUGH FINANCIAL RESOURCES POST-COVID-19 PANDEMIC

RO1: To analyse if there is a statistically significant relationship between financial capital and the performance of the women entrepreneurs.

RO2: To scrutinise if there is a statistically significant relationship between large amount of capital needed and the performance of the women entrepreneurs.

RO3: To examine if there is a statistically significant relationship between personal savings and the performance of the women entrepreneurs.

\section{Critical Literature Review}

This section covers the literature, which is relevant to achieve the purpose of the study.

\subsection{Women Entrepreneurship}

The involvement of women in entrepreneurship has escalated immensely worldwide as the consequence of a turbulently shifting society and hastened entrepreneurial interest. The number of women participating in entrepreneurial activities has expanded, according to (Cardella et al., 2020; Kanapathipillai \& Azam, 2019a; Ufuk \& Ozgen, 2001; Kelly et al., 2011). Even though the topic of women entrepreneurship has been getting incredible fame, the definition of women entrepreneurship is complex because different schools of thought classify it in different ways, thus making it problematic to agree on a flawless rationalisation of women entrepreneurship. According to the emerging literature, a women entrepreneur is the owner-head, owner-manager, or in other words, a women-head of an enterprise who can create new jobs and develop the economy (Hechevarría et al., 2019; Bouzekraoui \& Ferhane, 2017). Therefore, a women entrepreneur is a person who has founded, bought, or inherited an enterprise either by herself or with a partner or colleague of the opposite gender, who is liable for all the risks concerned in the business, who participates in all functions, governance control and management of the business enterprise (Vinesh, 2014).

\subsection{Business Performance}

The performance of women entrepreneurs has been an essential topic of research interest lately. According to (Chipfunde et al., 2021), performance is an elusive research topic with various explanations. Based on several research scholars, business performance is defined in terms of several variables, which are financial and sales progression, organizational effectiveness as well as expansion of employees (Zeb, 2019; Khaleque, 2018; Eniola \& Dada, 2018; Bouzekraoui \& Ferhane, 2017; Terziovski \& Samson, 2000). In other words, business performance is appraised using distinctive conceptions (Srinivasan et al., 1994). According to (Ibrahim et al., 2016; Dharmaratne, 2012), business performance is characterized by different dimensions that are difficult to regulate unless a combination of the objective and subjective methods is utilized. In addition, (Eniola \& Entebang, 2015; 2017) mention that a company can recognise its potencies and imperfections through business performance. Based on (Yusrinadini et al., 2019; Eniola \& Dada, 2018), an accurate business performance analysis is crucial to comprehend an enterprise's 
Kumaran Kanapathipillai, Subaneeswasri Narayanan, Sharvena Kumaran

ARE WOMEN ENTREPRENEURS' BUSINESS PERFORMANCES INFLUENCED BY

FINANCIAL RESOURCES? EMPOWERING WOMEN ENTREPRENEURS IN MALAYSIA

THROUGH FINANCIAL RESOURCES POST-COVID-19 PANDEMIC

attainments and malfunctions. Therefore, it could be said that business performance is a tactical technique utilized by firms to recognize their fortunes and misfortunes. Furthermore, various research scholars such as (Brown \& Caylor, 2009; Watts, 2003) inclined to use tangible resources such as financial capital when measuring business performance because they are simpler to quantify in terms of profitability, revenue, or return on investment which shows that the firm's targets are realised. Likewise, financial capital appears to be a popular measure when addressing performance by academic scholars (Murphy et al., 1996; Watts, 2003). Therefore, based on (Chipfunde et al., 2021; Eniola \& Dada, 2018), financial capital can be easily used when arbitrating how a firm is elevating its business performance. As financial capital is the primary measure of a firm's performance based on several research scholars, the business performance of a firm operated by a women entrepreneur could be studied based on exploring the financial capital utilization.

\subsection{Financial Capital and Business Performance of Women Entrepreneurs}

According to Van Praag et al. (2005), financial capital includes debt and equity and is termed as capital structure. Women favored internal sources of equity compared to external sources for their businesses, a strategy that may place greater limits on the amount of capital available for business development based on (Chaganti, 1986).

A significant factor for women entrepreneurs starting a venture seems to be financing, or it might be used as a principal concern that many entrepreneurs point out during the phase of a venture's development (Chipfunde et al., 2021; Al-Shami et al., 2019; Kanapathipillai \& Azam, 2019a; Danga et al., 2019).

Financial resources are vital for commencing and developing businesses (Mustafa et al., 2021; Chipfunde et al., 2021; Guzman \& Kacperczyk, 2019; Danga et al., 2019; Papaneek \& Harnis, 1980). Financial resources and the talent to secure the resources may make the difference in realizing the anticipated growth in a business after the Covid-19 lockdown is lifted. Scarcity of investment at preliminary phases can postpone or impede set up and may have a lasting influence on the firm (Kanapathipillai \& Azam, 2019b). Additionally, (Mahat et al., 2021; Nasri \& Muhammad, 2018; Storey, 1994) elucidated that inadequate capital at startup affects the entrepreneur's knack to secure additional finances from the banks. Women entrepreneurs' competence to raise startup capital, incapability to proffer collaterals or guarantees, failure to access formal and informal networks that could help them secure financial aids, and bankers' discrimination were frequently researched (Carter et al., 2001). Moreover, (Mustafa et al., 2021; Mahat et al., 2021; Alene, 2020; Brush et al., 2002) states that financial capital is a significant factor that aids small ventures to reinvent and flourish after the Covid-19 lockdown is revoked. This was supported by (Chipfunde et al., 2021; Beck \& Demirgu-Kunt, 2006), who said that financial capital provides working capital, foster more significant firm innovation and dynamism, enhances entrepreneurship, promotes more efficient asset allocation, and enhances the firm's ability to exploit growth opportunities. Additionally, economic variables such as financial capital are the main bases for the appearance of women 
Kumaran Kanapathipillai, Subaneeswasri Narayanan, Sharvena Kumaran

ARE WOMEN ENTREPRENEURS' BUSINESS PERFORMANCES INFLUENCED BY

FINANCIAL RESOURCES? EMPOWERING WOMEN ENTREPRENEURS IN MALAYSIA

THROUGH FINANCIAL RESOURCES POST-COVID-19 PANDEMIC

entrepreneurs (Kunkel, 1965). Furthermore, based on (Alene, 2020; Wiklund et al., 2009), financial capital provides resource slack, allowing experimentation with new strategies and innovative projects that might not be possible in an environment plagued by the Covid-19 pandemic. The business environment becomes more resource-constrained when the lockdown is eased, as many entrepreneurs rush to obtain resources. Therefore, financial resources will help women entrepreneurs to overcome decreased demand, decreased sales, unavailability of raw materials, and logistic issues after the Covid-19 lockdown is repealed, which in turn increases business performance.

On the other hand, potential entrepreneurs regularly acknowledge increasing hurdles and concerns when seeking financial capital to initiate their ventures. According to (Mahat et al., 2021; Memon, 2020; Al-Shami et al., 2019; Rao, 2014; Bardasi et al., 2011), access to finance is constantly recognized as a significant restraint to women entrepreneurs' development. Based on (Henry, 2020) women entrepreneurs were not given the financial support by their business alliances. According to (Mahat et al., 2021), approximately 190,000 Malaysian women entrepreneurs were affected by inadequate financial resources due to the onslaught of the Covid-19 pandemic. A previous study conducted by (Abou-Moghli and AlAbdallah, 2019; Guzman \& Kacperczyk, 2019; Syed \& Afida, 2015) reveals that funds are not readily available to women entrepreneurs in developing countries. A study conducted by (Alturki \& Braswell, 2010) in Saudi Arabia found that most women lack access to financial capital and have limited their business growth. Research conducted in India by (Kungwansupaphan \& Leihaothabam, 2016) found that all women entrepreneurs in their research highlighted that they faced financial difficulty in the startup phase of their enterprises. These researches indicate that women entrepreneurs faced challenges because of the limitations of financial capital. These researches also discovered that women entrepreneurs had access to both internal and external sources of finance but were not adequate to address all financial needs. Additionally, women entrepreneurs stress that they could not embark on their business and reach magnificence as planned due to underfinancing. According to (Carter et al., 2006), scholars have evidence that women entrepreneurs are prone to underfinance. According to a study conducted by (Shaw et al., 2001), in the United Kingdom, one of the barriers women entrepreneurs encounter during business startup is under-financing. To overcome this dilemma, many developing and developed countries have rendered financial support to women's small and medium businesses (Wang et al., 2020). Furthermore, as financial aid is crucial after the lifting of the lockdown, women entrepreneurs will require financial support to sustain their businesses (Dy \& Jayawarna, 2020).

\subsection{Large Amount of Financial Capital Needed and Business Performance of Women Entrepreneurs}

Most women entrepreneurs manage small ventures. Therefore, this may also attribute to the lesser capital accessible to women during their preliminary business setup (Kanapathipillai \& Azam, 2019a). Based on (Kauffman, 2009), companies created with 
Kumaran Kanapathipillai, Subaneeswasri Narayanan, Sharvena Kumaran

ARE WOMEN ENTREPRENEURS' BUSINESS PERFORMANCES INFLUENCED BY

FINANCIAL RESOURCES? EMPOWERING WOMEN ENTREPRENEURS IN MALAYSIA

THROUGH FINANCIAL RESOURCES POST-COVID-19 PANDEMIC

higher capital investment perform significantly better, but women-owned firms are customarily set up with smaller investments, leading to lower profits and survival rates. Based on (Al-Shami et al., 2019; Nasri \& Muhammad, 2018; Sitharam \& Hoque, 2016), if a women entrepreneur has the right amount of financial capital, there is a better chance for her to achieve higher performance. In support of this, (Welsh et al., 2018) cited that the amount of financial support required by a women entrepreneur is crucial as the business is most susceptible to failure at the initial stage of setup. Brixiova \& Kangoye (2016) conducted a study on women entrepreneurs in Swaziland and found that higher startup capital records higher sales performance than those with lesser amounts of financial capital. Moreover, a study conducted by (Salzman et al., 2006) discovered that starting and growing a business requires low-end capital for smaller businesses, highend capital for larger businesses. Women's access to capital is limited, not just in whether capital is used but also in the amount used.

Additionally, (Cooper et al., 1994) cited that the amount of capital raised is positively associated with the survival rate of businesses. The sum of startup capital is associated with the tactics undertaken by entrepreneurs. Similarly, (Cooper \& GimenoGascon, 1992) stated that six out of eight previous studies scrutinized relationships between initial capital and performance, found that additional financing was linked to more remarkable performance. Research by (Vann, 2011) in the United States discovered that female entrepreneurs who pursue higher financial resources achieved better returns and were confident of their business. Furthermore, research conducted in Mexico revealed that significant external sources of funding early in the life of business could improve the condition of the firm and contribute to its performance (Gutierrez et al., 2013). Contrarily, (Dzisi et al., 2015) researched in Ghana and discovered that financial capital negatively correlates with perceived performance. Based on (Dzisi et al., 2015), the women entrepreneurs had limited financial resources but could triumph in their business. However, this is only at the initial stages of the business operation (Dzisi et al., 2015). Moreover, financial resources are significant for women entrepreneurs' business growth after the Covid-19 lockdown is eased (Mustafa et al., 2021).

Furthermore, (Cole \& Wolken, 1995) found that women entrepreneurs were reluctant to borrow from the banks. Likewise, (Coleman \& Carsky, 1996) found that women were hesitant to borrow from financial institutions, but the reason was related to the business's functionality, magnitude, and age. Further evidence (Cole \& Wolken, 1995; Carter \& Rosa, 1996) shows that women entrepreneurs use less non-depository financial services and little trade credit. Similarly, (Brush, 1992; Verheul \& Thurik, 2001) reveal that women entrepreneurs' amount of financial capital to start or procure a business is comparatively smaller compared to male entrepreneurs. The majority of small firm owners, such as women, have few ambitions to grow their businesses but wish to remain viable and profitable (Freel et al., 2012). Equally, most small firm owners have no career ambitions to grow their firms into large multinationals. Thus, the women's preferred approach to finance their small firms is through retained profit, overdrafts, and credit cards (Hansen \& Hamilton, 2011). 
Kumaran Kanapathipillai, Subaneeswasri Narayanan, Sharvena Kumaran

ARE WOMEN ENTREPRENEURS' BUSINESS PERFORMANCES INFLUENCED BY

FINANCIAL RESOURCES? EMPOWERING WOMEN ENTREPRENEURS IN MALAYSIA

THROUGH FINANCIAL RESOURCES POST-COVID-19 PANDEMIC

\subsection{Personal Savings Used and Business Performance of Women Entrepreneurs}

Based on the research conducted by (Haynes \& Haynes, 1999; Hart \& Denison, 1987; Zimmer \& Aldrich, 1987), women entrepreneurs use informal financial sources such as funding from families and personal savings compared to formal sources of financial aid. Moreover, (Zhang et al., 2016; Bhide, 1992; Cohoon et al., 2010; Pelger \& Tchouvakhina, 2013; Gutierrez et al., 2013) indicated that most of the entrepreneurs used their personal savings that they saved to invest in their venture start-up. This was confirmed by (Orser, 2020; Orser et al., 2006) that women were more likely to use informal funding avenues, such as personal savings, to start and operate their businesses, especially after the Covid19 lockdown comes to an end. A study (Dzisi et al., 2015) revealed that women entrepreneurs' primary source of financial capital was from their personal savings. On the contrary (Carter et al., 2006) found that forty-three percent of women entrepreneurs used external funding sources to set up their business. Additionally, (Aspray \& Cohoon 2007, Robb \& Coleman, 2010) signified that women were much more likely to obtain financial capital from business partners.

Women entrepreneurs also face difficulties in obtaining loans because, on average, women request smaller financial aid. HKMA (2000) revealed that women entrepreneurs in Hong Kong relied mainly on personal savings as their primary funding source for start-up and expansion of business because banks needed collateral in funding the entrepreneurs. Furthermore, bankers recognize that women entrepreneurs lack entrepreneurial skills and therefore are reluctant to sanction their loans (Rashid \& Ratten, 2020; Abor \& Biekpe, 2006). Additionally, bankers often doubted women entrepreneurs' understanding of their business operations. This is a type of perception that women entrepreneurs have to deal with, according to (Carter et al., 2006). Moreover, (Mustafa et al., 2021; Carter et al., 2001; Rees \& Miazhevich, 2005) uncovered that women entrepreneurs face sexual stereotyping, inadequate personal assets, lack of credit track record, and ineptitude to secure informal financial networks.

In addition, (Kungwansupaphan \& Leihaothabam, 2016) conducted their research in India and found that women entrepreneurs who started a business did not have access to many available external sources of financial capital in the initial phase of their business venture. They confirmed that women were more likely to use informal funding avenues, such as personal savings, to start their businesses. In line with this, (Carter \& Anderson, 2001) found that in the United Kingdom, women's personal savings compose between $80 \%$ and $99 \%$ of initial capitalization. Reflecting on this (Bygrave, 2003) elucidated that entrepreneurs in emerging markets rely very heavily on informal sources of finance to start their businesses; these sources provided between $87 \%$ and $100 \%$ of the capital raised by entrepreneurs. Contrarily, (Coleman, 2002) argued that bankers do not discriminate against women entrepreneurs, but they must pay higher interest rates for their loans. Additionally, women entrepreneurs also have a lower tendency to obtain external funding. Moreover, according to (Scott, 2006), women entrepreneurs do not face problems securing start-up financial capital but are reluctant to pursue external financial resources. This can be supported by the findings of (Mustafa et al., 2021; Roper \& Scott, 
2009) that women entrepreneurs are not discouraged in their quest for financial resources for their business start-up. On the other hand, according to 'The Annual Small Business Survey,' women entrepreneurs are two percent more likely to have difficulty procuring funds and find it impossible to raise the finance to pursue their venture start-up (Roper \& Scott, 2009). Contrarily, (Pennisi, 2012) has uncovered that limited personal savings and lack of necessary informal capital have made women entrepreneurs turn to external financing with high-interest rates to start up their own business in developing countries. This shows that although entrepreneurial opportunities are vast in developing countries, inadequate personal savings limit women entrepreneurs' growth in developing countries.

Finally, evidence based on the (National Foundation of Women Business Owners, 2001) expresses that high growth business owners use a broader assortment of financial sources than lower growth business owners. This is reinforced by (Gundry \& Welsch, 2001), who found that high-performing women used a broader selection of financing opportunities such as personal savings, family, friends, and relatives to start businesses.

\subsection{Proposed Conceptual Framework}

This study aims to examine the influence of financial capital, amount of capital, and personal savings on the business performance of women entrepreneurs in Malaysia. Figure 1 shows the proposed conceptual framework developed based on the critical literature review to enlighten the relationship between the independent and dependent variables of this study.

Independent Variables

Dependent Variable

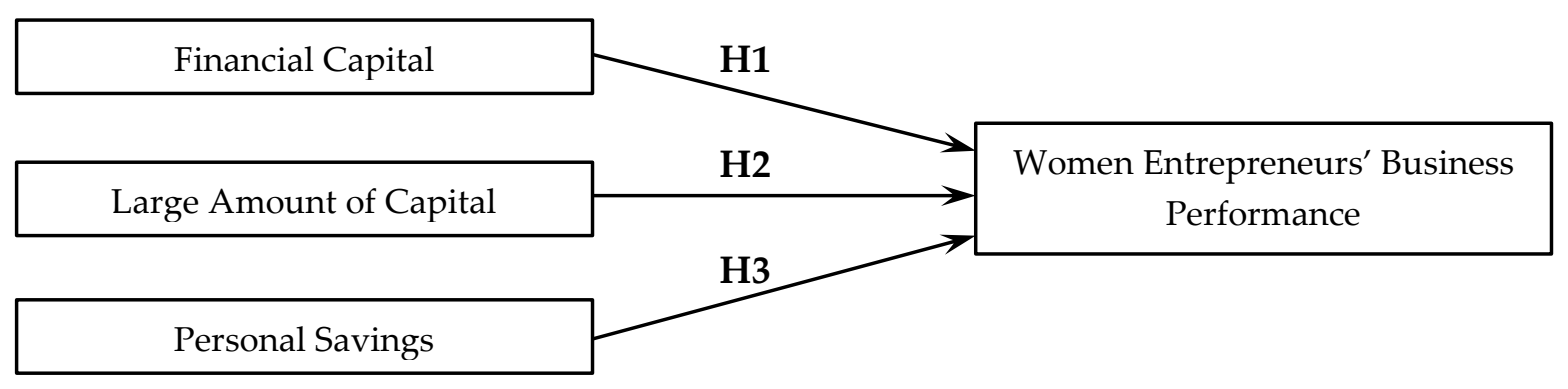

Figure 1: Proposed Conceptual Framework

\subsection{Research Hypothesis}

Based on the critical literature review presented, the following hypotheses were developed.

H1: There is a statistically significant relationship between financial capital and the business performance of the women entrepreneurs.

H2: There is a statistically significant relationship between large amount of capital needed and the business performance of the women entrepreneurs. 
Kumaran Kanapathipillai, Subaneeswasri Narayanan, Sharvena Kumaran

ARE WOMEN ENTREPRENEURS' BUSINESS PERFORMANCES INFLUENCED BY

FINANCIAL RESOURCES? EMPOWERING WOMEN ENTREPRENEURS IN MALAYSIA

THROUGH FINANCIAL RESOURCES POST-COVID-19 PANDEMIC

H3: There is a statistically significant relationship between personal savings and the business performance of the women entrepreneurs.

\section{Research Methodology}

This study aimed to gather the responses from the women entrepreneurs in Malaysia and acquire an insight into women entrepreneurs' business performance due to the influence of financial resources. A total of 860 self-administered structured questionnaires were distributed to the women entrepreneurs in Malaysia. The questionnaires used Likert's 5points scale varying from "Strongly disagree (1)" to "Strongly agree (5)". The survey instrument is comprised of five sections. The first section intended to obtain information about the women entrepreneurs' demographic profile, the second section generated data on financial capital. The third section generated data on the amount of financial capital needed, the fourth section provided data on personal savings. Finally, the fifth section provided data on the performance of the women entrepreneurs.

To obtain data regarding financial capital, the large amount of capital needed, and personal savings, which are the independent variables, the 5-point Likert's scale was adapted from (Kanapathipillai \& Azam, 2019a). Next, to attain data on the dependent variable, the performance of the women entrepreneurs, the questions were based on the literature by (Yusrinadini et al., 2019; Eniola \& Dada, 2018). The demographic profile contained 5 questions to identify the women entrepreneurs' backgrounds.

Upon testing the reliability, the Cronbach's Alpha values were all between $0.7<\alpha$ $<0.8$, which showed the internal consistency of the questionnaire is good. Table 1 shows the reliability of the instrument used in this research. The validity test was also conducted as the questionnaire was self-conducted. The validity of the questionnaire was certified by 3 entrepreneurs and 3 professors, and the committee agreed with minor alterations in the constructs. For the pilot study, 100 questionnaires were distributed to women operating their ventures. The reply served in amending some questions in the questionnaire.

Table 1: Reliability Analysis

\begin{tabular}{|l|c|}
\hline Variables & $\boldsymbol{\alpha}$-value \\
\hline Financial Capital & 0.764 \\
\hline Large Amount of Capital & 0.812 \\
\hline Personal Savings & 0.793 \\
\hline
\end{tabular}

\subsection{Population and Sampling}

The population of this study is women entrepreneurs in Malaysia. The total number of women entrepreneurs in Malaysia is 1,118,800 (DOSM, 2021). The (Krejcie \& Morgan, 1970) population and sample size tabulation were employed to obtain an appropriate sample size for this research from the population. Therefore, according to (Krejcie \& 
Morgan, 1970) computation, the representative sample size of women entrepreneurs is 384.

The snowball sampling technique was used to achieve the objective of this study. The women entrepreneurs voluntarily partook in the survey without any coercion. A total of 860 questionnaires were distributed to the women entrepreneurs in Peninsular Malaysia. A total of 336 questionnaires were received, which is approximately a $39.1 \%$ return rate. While collation, it was revealed that 24 out of 336 questionnaires that were collected were not thoroughly answered. Therefore, a total of 312 questionnaires were able to provide the data for this study. The analysis of the demographic factors was presented using percentages and frequencies. The regression procedure was used to analyse the relationship between the independent variables and the dependent variable. Additionally, to determine the strength of association between the variables, the correlation procedure was utilised.

\section{Findings and Interpretation}

The following sections present the results obtained from the study on the women entrepreneurs in Malaysia.

\subsection{Demographics of Women Entrepreneurs}

Table 2: Women Entrepreneur's Profile (N=312)

\begin{tabular}{|l|l|c|c|}
\hline Demographics & Category & Frequency & Percentage \\
\hline \multirow{5}{*}{ Age } & $21-30$ & 36 & $11.5 \%$ \\
\cline { 2 - 4 } & $31-40$ & 187 & $59.9 \%$ \\
\cline { 2 - 4 } & $41-50$ & 51 & $16.3 \%$ \\
\cline { 2 - 4 } & $51-60$ & 38 & $12.2 \%$ \\
\hline \multirow{5}{*}{ Academic Qualification } & SPM/STPM (Secondary) & 26 & $8.3 \%$ \\
\cline { 2 - 4 } & Diploma & 89 & $28.5 \%$ \\
\cline { 2 - 4 } & Undergraduate Degree & 134 & $42.9 \%$ \\
\cline { 2 - 4 } & Postgraduate Degree & 63 & $20.2 \%$ \\
\hline \multirow{5}{*}{ Years of Experience of Business Sector } & Service & 142 & $45.5 \%$ \\
\cline { 2 - 4 } & Manufacturing & 14 & $4.5 \%$ \\
\cline { 2 - 4 } & Agricultural & 71 & $22.8 \%$ \\
\cline { 2 - 4 } & Retail & 85 & $27.2 \%$ \\
\hline \multirow{5}{*}{ Ethnicity } & $<10$ & 215 & $15.1 \%$ \\
\cline { 2 - 4 } & $10-20$ & 50 & $68.9 \%$ \\
\cline { 2 - 4 } & $>20$ & 46 & $16.0 \%$ \\
\hline & Indian & 126 & $40.4 \%$ \\
\cline { 2 - 4 } & Chinese & 32 & $34.6 \%$ \\
\cline { 2 - 4 } & Malay & $10.3 \%$ \\
\cline { 2 - 4 } & Others & 32 & \\
\hline
\end{tabular}


A majority of $187(59.9 \%)$ respondents were in the 31-40 age groups. Based on the academic qualification, a majority of 134 (42.9\%) women entrepreneurs have attained their undergraduate degrees. In terms of the type of business sector, a vast majority of $142(45.5 \%)$ respondents were involved in the service sector. A majority of 215 (68.9\%) women entrepreneurs have between 10 to 20 years of business experience. In terms of ethnicity, the majority of 126 (40.4\%) women entrepreneurs are Chinese descendants.

\subsection{Financial Capital and the Performance of the Women Entrepreneurs}

RO1: The first objective of the research sought to establish the relationship between financial capital and the performance of the women entrepreneurs. To achieve this objective, the following hypothesis was formulated.

H1: There is a statistically significant relationship between financial capital and the performance of the women entrepreneurs.

The regression procedure was used to test the relationship between two quantitative variables, financial capital and the performance of the women entrepreneurs if there is a theoretical basis for a cause and effect between these two variables. The purpose is to obtain a regression model to explain how a change in financial capital affects the performance of women entrepreneurs. In this case, the financial capital is said to be the cause (independent variable), and the variable performance of the women entrepreneur is said to be the effect (dependent variable). Thus, the objective of this analysis using regression is:

The regression equation used to measure the relationship is as follows:

$$
Y=\beta_{0}+\beta_{1} X+\varepsilon,
$$

where,

$\beta_{0}$ is the intercept,

$\beta_{1}$ is the slope and $\varepsilon$ is the residual term (Chinna \& Choo, 2015).

$\mathrm{X}=$ Independent Variable (Financial Capital)

$\mathrm{Y}=$ Dependent Variable (Performance of the Women Entrepreneurs)

Next, the correlation procedure was used to test the strength of association between two quantitative variables, financial capital and the performance of the women entrepreneurs. The extent to which the two variables covary and the direction was quantified mathematically using Pearson's correlation coefficient. The value of Pearson's correlation coefficient ranges between -1 and +1 and the correlation coefficient $(R>0.3)$. Based on the (Cohen, 1988) criterion, $(\mathrm{R}>0.3)$ is considered to be sizable. Thus, the following analysis was performed:

The pertinent results are summarized in Table $3 a, b, c$. 
Kumaran Kanapathipillai, Subaneeswasri Narayanan, Sharvena Kumaran

ARE WOMEN ENTREPRENEURS' BUSINESS PERFORMANCES INFLUENCED BY

FINANCIAL RESOURCES? EMPOWERING WOMEN ENTREPRENEURS IN MALAYSIA

THROUGH FINANCIAL RESOURCES POST-COVID-19 PANDEMIC

Table 3: Model Summary, ANOVA and Coefficients

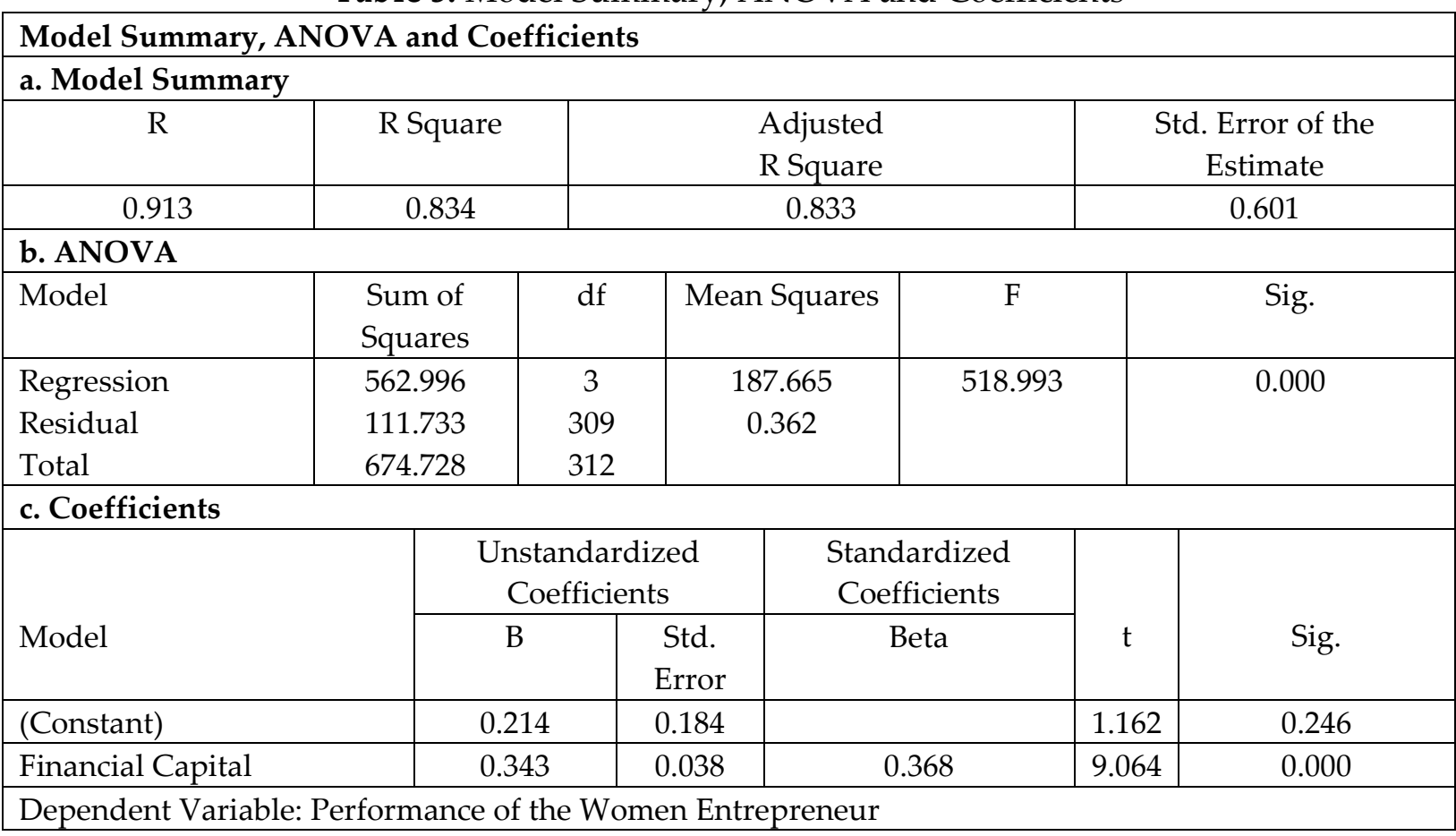

Upon computing the data using one-way analysis of variance (ANOVA) the ' $\mathrm{F}$ ' statistics to test the hypotheses for the sample population $(\mathrm{N}=312),(\mathrm{F}=518.99 ; \mathrm{p}<0.001)$. Therefore, $\mathrm{H} 1$ is supported by data meaning there is a statistically significant relationship between financial capital and the performance of the women entrepreneur.

The Pearson's Bivariate Correlations test revealed the following results for the association between financial capital and the performance of the women entrepreneur. The Pearson's Bivariate Correlations was performed on the predictor (financial capital) $\mathrm{R}$ $=0.913$, which is more than 0.3 and between -1.0 and +1.0 . The $p$-value is less than 0.001 . Thus, this implies a strong positive association between financial capital and the performance of the women entrepreneur.

The results are in Table 3a. Model Summary shows that $(\mathrm{R} 2=0.834)$. This means $83.4 \%$ of the variation in performance is explained by financial capital. This also implies that financial capital has a strong relationship with the performance of women entrepreneurs. From the ANOVA in Table $3 b$ the $F=518.993 ; p<0.001$ ). This reveals that the predictor variables (financial capital) can predict the dependent variable (performance of the women entrepreneurs). This implies that there is a significant relationship between the performance of women entrepreneurs and financial capital.

From Table 3c Coefficients, show that financial capital adds significantly to the performance of the women entrepreneurs $(B=0.343$; $p<0.001)$. Thus, this implies that there is a significant relationship between the predictor variable (financial capital) and dependent variable performance of women entrepreneurs.

Based on Table 3c Coefficients, the linear regression equation is as follows: 
Performance $=0.214+0.343$ (financial capital)

Thus, women entrepreneurs' business performance is expected to increase by 0.343 units for every one unit increase in financial capital.

\subsection{Relationship between Large Amount of Capital Needed and Performance}

$\mathbf{R O}_{2}$ : The second objective of the research sought to establish the relationship between large amount of capital and the performance of the women entrepreneurs. To achieve this objective, the following hypothesis was formulated.

H2: There is a statistically significant relationship between large amount of capital and the performance of the women entrepreneurs.

The regression procedure was used to test the relationship between two quantitative variables, a large amount of capital and the performance of the women entrepreneurs if there is a theoretical basis for a cause and effect between these two variables. The purpose is to obtain a regression model to explain how a change in a large amount of capital affects the performance of women entrepreneurs. In this case, the large amount of capital is the cause (independent variable), and the variable performance of the women entrepreneur is said to be the effect (dependent variable). Thus, the objective of this analysis using regression is:

The regression equation used to measure the relationship is as follows:

$$
Y=\beta_{0}+\beta_{1} X+\varepsilon,
$$

where,

$\beta_{0}$ is the intercept,

$\beta_{1}$ is the slope and $\varepsilon$ is the residual term (Chinna \& Choo, 2015).

$\mathrm{X}=$ Independent Variable (Large amount of capital)

$\mathrm{Y}=$ Dependent Variable (Performance of the Women Entrepreneurs)

Next, the correlation procedure was used to test the strength of association between two quantitative variables, a large amount of capital and the performance of the women entrepreneurs. The extent to which the two variables covary and the direction was quantified mathematically using Pearson's correlation coefficient. The value of Pearson's correlation coefficient ranges between -1 and +1 and the correlation coefficient $(R>0.3)$. Based on the (Cohen, 1988) criterion, $(R>0.3)$ is considered to be sizable. Thus, the following analysis was performed:

The pertinent results are summarized in Table $4 a, b, c$. Upon computing the data using one-way analysis of variance (ANOVA) in Table $4 \mathrm{~b}$ the ' $\mathrm{F}$ ' statistics to test the hypotheses for the sample population $(\mathrm{N}=312),(\mathrm{F}=1168.27) ; \mathrm{p}<0.001)$. Therefore, $\mathrm{H} 2$ is supported by data meaning there is a statistically significant relationship between large amount of capital needed and the performance of the women entrepreneur. 
Kumaran Kanapathipillai, Subaneeswasri Narayanan, Sharvena Kumaran ARE WOMEN ENTREPRENEURS' BUSINESS PERFORMANCES INFLUENCED BY FINANCIAL RESOURCES? EMPOWERING WOMEN ENTREPRENEURS IN MALAYSIA THROUGH FINANCIAL RESOURCES POST-COVID-19 PANDEMIC

Table 4: Model Summary, ANOVA and Coefficients

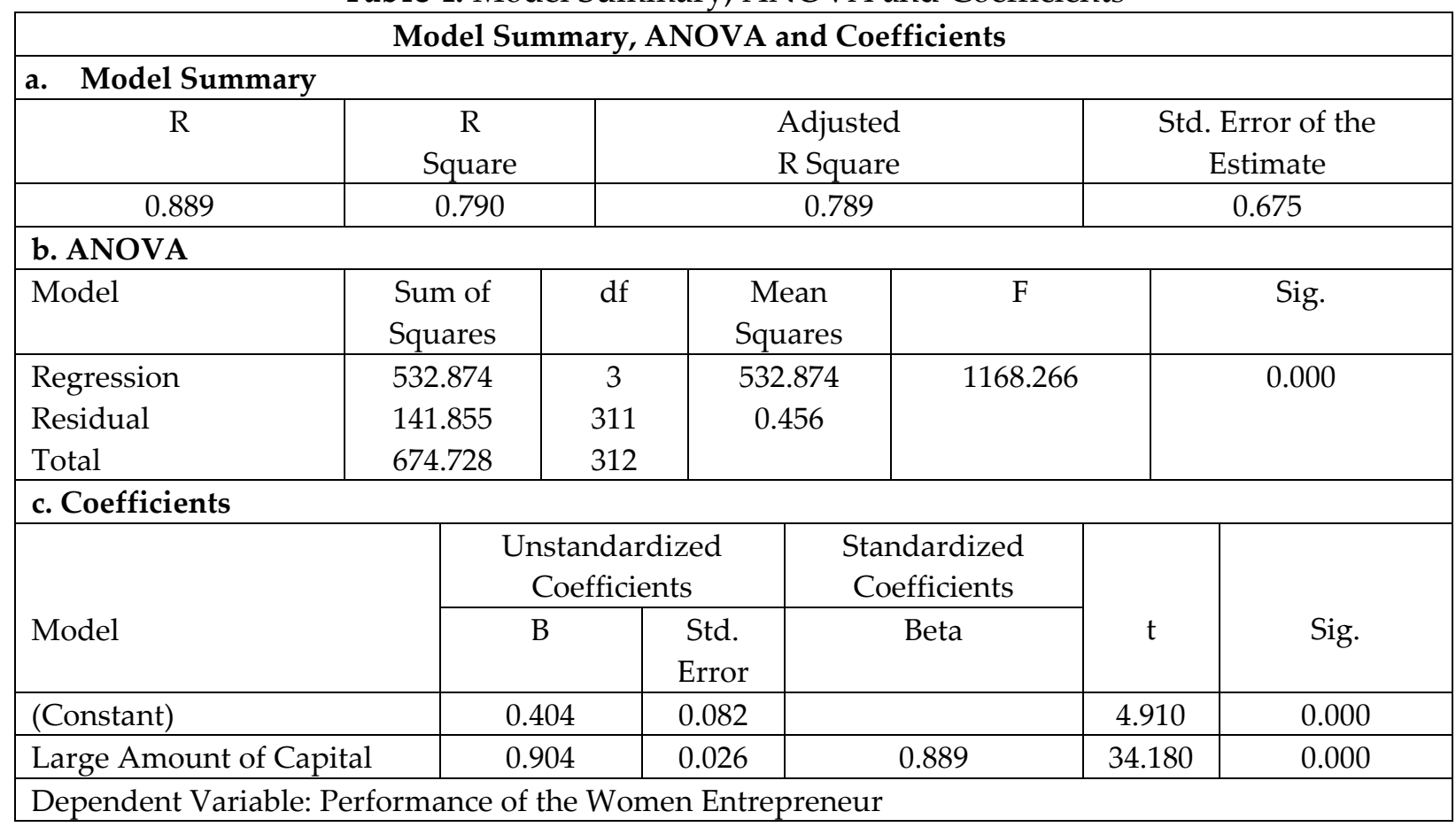

The Pearson's Bivariate Correlations test revealed the following results for the association between large amount of capital needed and the performance of the women entrepreneur.

The Pearson's Bivariate Correlations was performed on the predictor (a large amount of capital needed) $\mathrm{R}=0.889$, which is more than 0.3 and between -1.0 and +1.0 . The $\mathrm{p}$-value is less than 0.001 . Thus, this implies a strong positive association between the need for a large amount of capital and the performance of the women entrepreneur. From Table $4 \mathrm{a}$, a large amount of capital needed gives $\mathrm{R} 2=0.790, \mathrm{p}<0.001$ ), which means that $79.0 \%$ of the variation in performance can be explained by the predictor (a large amount of capital needed). It also shows a strong significant relationship between the predictor variable (a large amount of capital needed) and the dependent variable (performance of the women entrepreneurs).

Based on Table 4c Coefficients, the linear regression equation is as follows:

Performance $=0.404+0.904$ (large amount of capital needed) .

Thus, women entrepreneurs' business performance is expected to increase by 0.904 units for every one unit increase in large amount of capital needed.

\subsection{Relationship between Personal Savings and Performance}

$\mathbf{R O}_{3}$ : The third objective of the research sought to establish the relationship between personal savings and the performance of the women entrepreneurs. To achieve this objective, the following hypothesis was formulated. 
H3: There is a statistically significant relationship between personal savings and the performance of the women entrepreneurs.

The regression procedure was used to test the relationship between two quantitative variables, personal savings and the performance of the women entrepreneurs if there is a theoretical basis for a cause and effect between these two variables. The purpose is to obtain a regression model to explain how a change in personal savings affects the performance of women entrepreneurs. In this case, the personal savings is said to be the cause (independent variable), and the variable performance of the women entrepreneur is said to be the effect (dependent variable).

Thus, the objective of this analysis using regression is:

The regression equation used to measure the relationship is as follows:

$$
\mathrm{Y}=\beta_{0}+\beta_{1} \mathrm{X}+\varepsilon,
$$

where,

$\beta_{0}$ is the intercept, $\beta_{1}$ is the slope and $\varepsilon$ is the residual term (Chinna \& Choo, 2015).

$X=$ Independent Variable (personal savings)

$\mathrm{Y}=$ Dependent Variable (Performance of the Women Entrepreneurs)

Next, the correlation procedure was used to test the strength of association between two quantitative variables, personal savings and the performance of the women entrepreneurs. The extent to which the two variables covary and the direction was quantified mathematically using Pearson's correlation coefficient. The value of Pearson's correlation coefficient ranges between -1 and +1 and the correlation coefficient $(R>0.3)$. Based on the (Cohen, 1988) criterion, $(R>0.3)$ is considered to be sizable. Thus, the following analysis was performed:

The pertinent results are summarized in Table $5 a, b, c$.

Table 5: Model Summary, ANOVA and Coefficients

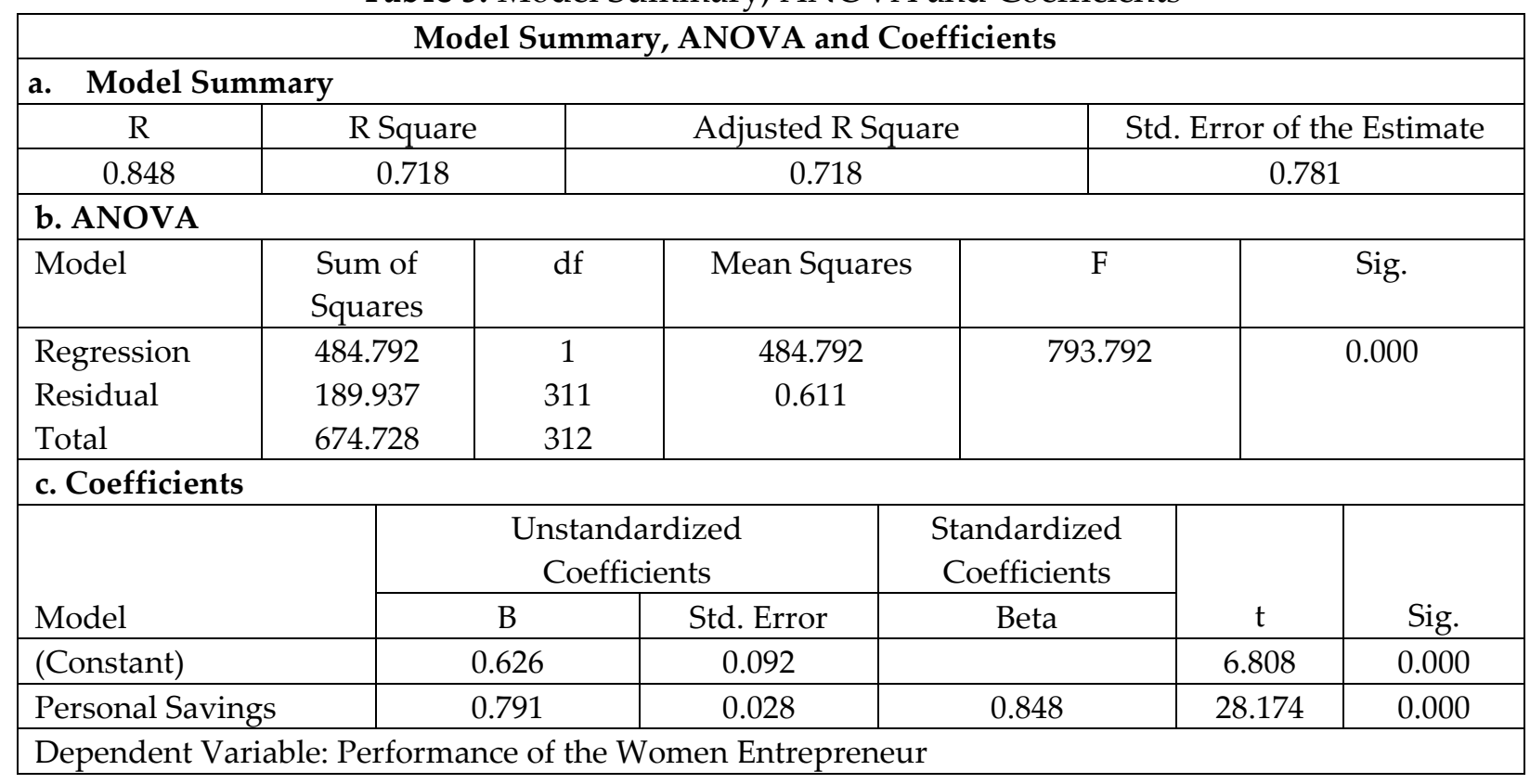


Kumaran Kanapathipillai, Subaneeswasri Narayanan, Sharvena Kumaran

ARE WOMEN ENTREPRENEURS' BUSINESS PERFORMANCES INFLUENCED BY

FINANCIAL RESOURCES? EMPOWERING WOMEN ENTREPRENEURS IN MALAYSIA

THROUGH FINANCIAL RESOURCES POST-COVID-19 PANDEMIC

Upon computing the data using one-way analysis of variance (ANOVA) the ' $\mathrm{F}$ ' statistics to test the hypotheses for the sample population $(\mathrm{N}=312),(\mathrm{F}=793.79$; $\mathrm{p}<0.001)$. Therefore, H3 is supported by data, meaning there is a statistically significant relationship between personal savings and the performance of the women entrepreneur. The Pearson's Bivariate Correlations test revealed the following results for the association between personal savings and the performance of the women entrepreneur.

The Pearson's Bivariate Correlations was performed on the predictor personal savings $R=0.848$, which is more than 0.3 and between -1.0 and +1.0 . The $p$-value is less than 0.001 . Thus, this implies a positive association between personal saving and the performance of the women entrepreneur. This predictor (personal savings) generated $(\mathrm{R} 2=0.718$, $\mathrm{p}$-value $<0.001)$, means that the predictor personal savings can explain $71.8 \%$ of the variation in performance. It also shows a strong significant relationship between the predictor variable personal savings and the dependent variable performance of the women entrepreneurs.

Based on Table 5c Coefficients, the linear regression equation is as follows:

Performance $=0.626+0.791$ (personal savings) .

Thus, women entrepreneurs' business performance is expected to increase by 0.791 units for every one unit increase in personal savings.

\section{Discussion}

This section enlightens the results and discussions concerning the relationship between the independent variable financial capital, a large amount of capital needed and personal savings, and the dependent variable, which is the women entrepreneurs' business performance.

\subsection{Financial Capital and the Women Entrepreneurs' Business Performance}

The first objective of the research was to establish the relationship between financial capital and the performance of women entrepreneurs in Malaysia. To realize this objective, it was hypothesized that financial capital has a statistically significant relationship to the performance of women entrepreneurs.

To determine the relationship between financial capital and the performance of women entrepreneurs, linear regression was first used. Then, Pearson's correlation coefficient was observed to determine the size and direction of the relationship and whether it was statistically significant. The results showed that financial capital is statistically significant ( $p$-value less than $0.001, \mathrm{R} 2=0.834$ ). Therefore, $83.4 \%$ of the variation in performance can be explained by financial capital.

This shows that the results are consistent with the literature, which suggests that financial capital is a significant determinant of the performance of women entrepreneurs. As elucidated by (Chipfunde et al., 2021; Danga et al., 2019; Kanapathipillai \& Azam, 
Kumaran Kanapathipillai, Subaneeswasri Narayanan, Sharvena Kumaran

ARE WOMEN ENTREPRENEURS' BUSINESS PERFORMANCES INFLUENCED BY

FINANCIAL RESOURCES? EMPOWERING WOMEN ENTREPRENEURS IN MALAYSIA

THROUGH FINANCIAL RESOURCES POST-COVID-19 PANDEMIC

2019a; Cooper, 1971), a woman is encouraged to choose entrepreneurship if there is the availability of venture capital. In a study (Mustafa et al., 2021; Mahat et al., 2021; Brush et al., 2002; Beck \& Demirgu-Kunt, 2006), financial capital is significant in enabling a small business to revolutionize, develop, generate jobs prospects, allocate resources and exploit opportunities. Additionally, (Dy \& Jayawarna, 2020) cited that financial capital is significant for women entrepreneurs when the Covid-19 lockdown ends. According to (Alene, 2020; Guzman \& Kacperczyk, 2019; Wiklund et al., 2009; Kunkel, 1965), economic variables such as financial capital are the foremost determinants for the manifestation of entrepreneurs and increase the ability to innovate and pursue new opportunities.

Financial capital allows new firms to develop by helping them to manipulate growth and investment opportunities. In particular, access to finance adds to growth through the entry of new firms and creating a thriving private sector with a wellorganized distribution of resources and is mainly suitable for firm development, specifically for small businesses owned by women entrepreneurs. Additionally, (Papaneek \& Harnis, 1980) has elucidated that the availability of adequate finances is a primary motivation for entrepreneurial activities.

According to (Cardella et al., 2020; Kungwansupaphan \& Leihaothabam, 2016; Syed \& Afida, 2015; Rao, 2014; Alturki \& Braswell, 2010; Bardasi et al., 2011), availability of finance is frequently identified as a significant issue for women in business. Based on the study (Salzman et al., 2006), starting and growing a business requires low-end capital for smaller businesses and high-end capital for larger businesses. However, women business owners regularly name access to capital as a significant obstacle to performance regardless of the amount needed (Cardella et al., 2020). In contrast, findings of (Dzisi, 2015) showed that financial capital has a negative relationship with perceived performance. This means that women with little in the way of financial resources tend to perform better.

This study shows that women entrepreneurs can make even more extraordinary contributions to employment and economic development after the Covid-19 lockdown is lifted. These finding parallels previous research (Dy \& Jayawarna, 2020; Hechevarría et al., 2019; Guzman \& Kacperczyk, 2019). Nevertheless, this can only be achieved if the women entrepreneurs have financial capital (Mustafa et al., 2021; Cardella et al., 2020). Thus, the findings of this research prove that financial capital is significant for the performance of the women entrepreneurs in Malaysia post Covid-19 pandemic. Therefore, invalidating the findings of (Dzisi et al., 2015). Thus, hypothesis H1 is supported by data, and the findings of this study were able to narrow the gap in the literature and validate that financial capital is statistically significant for the women entrepreneurs' business performance.

\subsection{Large Amount of Capital Needed and the Women Entrepreneurs' Business Performance}

The second objective of the research was to establish the relationship between a large amount of financial capital needed and the performance of women entrepreneurs in 
Kumaran Kanapathipillai, Subaneeswasri Narayanan, Sharvena Kumaran

ARE WOMEN ENTREPRENEURS' BUSINESS PERFORMANCES INFLUENCED BY

FINANCIAL RESOURCES? EMPOWERING WOMEN ENTREPRENEURS IN MALAYSIA

THROUGH FINANCIAL RESOURCES POST-COVID-19 PANDEMIC

Malaysia. To realize this objective, it was hypothesized that a large amount of financial capital has a statistically significant relationship to the performance of women entrepreneurs. A study conducted on women entrepreneurs in Swaziland by (Brixiova \& Kangoye, 2016) shows that higher start-up capital records higher sales performance than those with lesser amounts of financial capital. For women entrepreneurs, formal finance sources of start-up capital are also associated with higher sales. The analyses from this research also suggest the significance of a large amount of capital needed during business start-up for the performance of the women entrepreneurs in Malaysia. This independent variable (a large amount of capital needed) shows $(\mathrm{R} 2=0.790 ; \mathrm{p}<0.001)$, which means that $79.0 \%$ of the variation in performance can be explained by a large amount of capital needed. It also shows a strong significant relationship between the independent variable (a large amount of capital needed) and the dependent variable (performance of the women entrepreneurs). In order to reinforce this finding (Nasri \& Muhammad, 2018; Kauffman, 2009) study shows that firms that start with higher levels of capital show significantly better performance; women-owned firms typically start with less capital and therefore underperform in terms of profitability and survival as cited by (Cole \& Wolken, 1995; Carter \& Rosa, 1996). In addition, according to (Chipfunde et al., 2021; Welsh et al., 2018; Cooper et al., 1992; 1994), the amount of capital raised should be positively associated with venture survival. There is a long tradition of studying the financing of new firms, a part of the entrepreneurial process that is central to the assembly of resources. The amount of initial capital is related to the initial strategy that might be pursued. For instance, more initial capital permits a merchant to carry a broader mix of goods or a high technology firm to undertake more ambitious projects. More initial capital also buys time while the entrepreneur learns or overcomes problems. (Cooper and Gimeno-Gascon, 1992; 1994) reported that, of eight prior studies that examined relationships between initial capital and performance, six found that more capital was associated with better performance. Additionally, (Gutierrez et al., 2013; Vann, 2011) discovered that female entrepreneurs who seek greater financial resources for their business experienced higher returns, as the women felt more secure of their business and could improve the condition of the business and contribute to its performance.

On the other hand (Dzisi et al., 2015) found that financial capital negatively affects women entrepreneurs' performance, and women entrepreneurs could achieve performance with limited financial resources. However, this research shows that women entrepreneurs in Malaysia need a large amount of capital to attain better performance in their business. This parallels previous studies (Al-Shami et al., 2019; Nasri \& Muhammad, 2018; Sitharam \& Hoque, 2016). Therefore, obtaining the right amount of financial capital after lifting the Covid-19 lockdown is a significant factor for the women entrepreneurs' business performance and survival. This can be supported by the findings of (Mustafa et al., 2021). Hence, the findings of this research and previous studies contradict the findings of (Dzisi et al., 2015). Thus, hypothesis $\mathrm{H} 2$ is supported by data, and the findings of this study were able to narrow the gap in the literature and verify that a large amount of 
Kumaran Kanapathipillai, Subaneeswasri Narayanan, Sharvena Kumaran

ARE WOMEN ENTREPRENEURS' BUSINESS PERFORMANCES INFLUENCED BY

FINANCIAL RESOURCES? EMPOWERING WOMEN ENTREPRENEURS IN MALAYSIA

THROUGH FINANCIAL RESOURCES POST-COVID-19 PANDEMIC

financial capital is statistically significant for the women entrepreneurs' business performance.

\subsection{Personal Savings and the Women Entrepreneurs' Business Performance}

The third objective of the research was to establish the relationship between personal savings and the performance of women entrepreneurs in Malaysia. To realize this objective, it was hypothesized that personal savings have a significant relationship to the performance of women entrepreneurs. The finding showed that most women entrepreneurs used their own personal savings to start up their businesses. This independent variable (personal savings) generated $(\mathrm{R} 2=0.718$, $\mathrm{p}$-value $<0.001)$, this means that personal savings can explain $71.8 \%$ of the variation in performance. It also shows a strong significant relationship between the independent variable (personal savings) and the dependent variable (performance of the women entrepreneurs). The Ghanaian women entrepreneurs' study by (Dzisi, et al., 2015) reveals that personal savings provided the most crucial source of cash capital for them. These personal savings were obtained as a result of the women entrepreneurs' self-sacrifice and hard work. Moreover, in most cases, because they could not save much, they had little capital to start with, and profits were ploughed back into the business for reinvestment.

Furthermore, research conducted by (Orser, 2020; Zhang et al., 2016; Dzisi et al., 2015; Pelger \& Tchouvakhina, 2013; Gutierrez et al., 2013) revealed that female entrepreneurs finance their investment through internal financial capital such as personal savings at the start-up of business which affects the business performance. According to (HKMA, 2000), women entrepreneurs in Hong Kong depended mainly on personal savings as their principal financial resource for the start-up and development of their business because banks required collateral that the women entrepreneurs could not provide.

Based on (Orser, 2020; Orser et al., 2006), women were more likely to use informal funding avenues, such as personal savings, to start their businesses. A survey conducted by (Cohoon et al., 2010) also found that the majority of the entrepreneurs established their business with money from their personal savings. To support this further, (Bhide, 1992) indicates that most businesses were initiated with the founders' personal savings accrued over time. In contrast, women entrepreneurs with less than ten years in business had access to financial capital from government schemes during the initial business start-up phase. (Orser et al., 2006) findings also indicate that financial capital remains a significant feature even after the initial start-up phase of the business.

In addition, a study conducted by (Mahat et al., 2021; Chipfunde et al., 2021; Kungwansupaphan \& Leihaothabam, 2016) found that women entrepreneurs who started their business did not have access to many available external sources of financial capital. Therefore, the women entrepreneurs used personal savings to start their ventures. This similar discovery can be confirmed in this research where the women entrepreneurs in Malaysia used their personal savings during the business start-up and achieved performance. This can also be supported by previous research conducted by 
Kumaran Kanapathipillai, Subaneeswasri Narayanan, Sharvena Kumaran

ARE WOMEN ENTREPRENEURS' BUSINESS PERFORMANCES INFLUENCED BY

FINANCIAL RESOURCES? EMPOWERING WOMEN ENTREPRENEURS IN MALAYSIA

THROUGH FINANCIAL RESOURCES POST-COVID-19 PANDEMIC

(Carter \& Anderson, 2001) in the United Kingdom. Additionally, (Bygrave, 2003) also clarified that women entrepreneurs depend on self-raised finance to operate their business. Contrarily, (Pennisi, 2012) discovered that women entrepreneurs turn to external financing with high interest rates to start up their businesses due to limited personal savings. This shows that although entrepreneurial opportunities are vast in developing countries like Malaysia, inadequate personal savings limit women entrepreneurs' growth.

Therefore, it can be deduced that women entrepreneurs in this study also attain business performance by utilizing their personal savings. This finding can be supported by (Gundry \& Welsch, 2001), who previously found that high-performing women entrepreneurs used personal savings to start their businesses and attain more remarkable performance. Therefore, personal savings could also be a significant financial resource for women entrepreneurs after the Covid-19 lockdown is revoked. The discovery of this research and the previous findings is evidence that personal savings could save the women entrepreneurs' businesses and lead to better performance when the Covid-19 lockdown is relaxed. Thus, hypothesis H3 is supported by data and the findings of this study were able to narrow the gap in the literature and prove that personal saving is significant for the women entrepreneurs' business performance.

\section{Conclusion}

This section of the conclusion is based on the relationship between financial capital, a large amount of capital needed, personal savings, and women entrepreneurs' performance in Malaysia.

\subsection{Financial Capital and the Women Entrepreneurs' Business Performance}

Research question one was addressed as follows: Is there a statistically significant relationship between financial capital and the performance of women entrepreneurs? Studies conducted by (Chipfunde et al., 2021; Mahat et al., 2021; Daga et al., 2019; Brush et al., 2002) suggested that financial capital is one of the main ingredients in enabling a small business to innovate, grow and create jobs. According to (Dy \& Jayawarna, 2020), financial capital is significant for women entrepreneurs ventures after the Covid-19 lockdown is revoked. Furthermore, according to (Alene, 2020; Beck \& Demirgu-Kunt, 2006), financial capital provides working capital, fosters greater firm innovation and dynamism, enhances entrepreneurship, promotes more efficient asset allocation, and enhances the firm's ability to exploit growth opportunities. The survey response indicated that the findings of this research prove that financial capital is statistically significant for the performance of the women entrepreneurs in Malaysia after the Covid19 lockdown is lifted. Without financial capital, the women entrepreneurs will not be able to make the necessary investment into their ventures after the government decides to open the business sectors. This will, in turn, hinder women entrepreneurs from achieving their intended business objectives when they start operating in the new norms. Thus, this 
Kumaran Kanapathipillai, Subaneeswasri Narayanan, Sharvena Kumaran

ARE WOMEN ENTREPRENEURS' BUSINESS PERFORMANCES INFLUENCED BY

FINANCIAL RESOURCES? EMPOWERING WOMEN ENTREPRENEURS IN MALAYSIA

THROUGH FINANCIAL RESOURCES POST-COVID-19 PANDEMIC

study has addressed, concluded, and narrowed the gap in the literature with regards to the significance of financial capital for the performance of the women entrepreneurs postCovid-19 pandemic.

\subsection{Large Amount of Capital Needed and the Women Entrepreneurs' Business Performance}

Responses for the second independent variable (a large amount of capital needed) indicated a strong statistically significant relationship between the large amount of capital needed during business start-up and the performance of the women entrepreneur. A past study by (Nasri \& Muhammad, 2018; Sitharam \& Hoque, 2016; Kauffman, 2009) indicates that women entrepreneurs who start with higher levels of capital show significantly better performance. In addition, several prior studies also focused on the significance of the large amount of capital needed as a critical performance factor in several areas for women entrepreneurs (Kanapathipillai \& Azam, 2019a; \& Kangoye, 2016; Gutierrez et al., 2013; Vann, 2011; Cooper et al., 1994; Cooper and Gimeno-Gascon, 1992) and contributed to this research study on the women entrepreneurs in Malaysia. Women entrepreneurs need a large amount of financial aid after the Covid-19 lockdown has been lifted. An enormous financial source will enable the women entrepreneurs to reinvest in their ventures and attain more extraordinary business performance. Thus, this study has addressed, concluded, and narrowed the gap in the literature regarding the significance of a large amount of financial capital needed for the performance of the women entrepreneur post-Covid-19 pandemic.

\subsection{Personal Savings and the Women Entrepreneurs' Business Performance}

Responses for the third independent variable (personal savings) indicated a strong statistically significant relationship between personal savings and the performance of the women entrepreneur in Malaysia. In previous research conducted by (Mahat et al., 2021; Chipfunde et al., 2021; Orser, 2020; Zhang et al., 2016; Dzisi et al., 2015) discloses that personal savings provided the most crucial source of cash capital for women entrepreneurs and contributes to this research study on the women entrepreneurs in Malaysia. Although many women entrepreneurs have lost their business income due to the Covid-19 pandemic lockdown, this research indicates that those women who still have some of their personal savings implied that they could utilise their savings to reinvest and redevelop their business and finally achieve business performance when the Covid-19 lockdown ends. Thus, this study has addressed, concluded, and narrowed the gap in the literature with regards to the significance of personal savings for the performance of the women entrepreneur post-Covid-19 pandemic. 


\section{Limitations and Future Research}

The focus of this study was only on the women entrepreneurs in Peninsula Malaysia. Therefore, research can be conducted on a larger scale involving women entrepreneurs in East Malaysia to gain additional knowledge on this area of study.

\section{Acknowledgments}

The authors would like to express their sincere gratitude to all the women entrepreneurs for allowing the authors to conduct this study amid the Covid-19 pandemic and value the time they have used in responding to the questionnaires.

\section{Conflict of Interest}

The authors of this research would like to declare that there are no conflicts of interest linked with this research, and this research was not sponsored by anyone that could have influenced its outcomes. As the researchers of this study, the authors validate its novelty and assert that this study has not been published previously, and verify that it is not presently being considered for publication elsewhere.

\section{About the Authors}

The authors are academics and independent researchers who have been involved in scholarly and research activities.

\section{References}

Abor, J. \& Biekpe, N. (2006). Small business financing initiatives in Ghana. Problems and Perspectives in Management, 4(3), 69-77.

Abou-Moghli, A. A., \& Al-Abdallah, G. M. (2019). A systematic review of women entrepreneurs opportunities and challenges in Saudi Arabia. Journal of Entrepreneurship Education. 22(6). Retrieved from: https://www.abacademies.org.

Alam, S. S., Jani, M. F. M., \& Omar, N. A., (2011). An empirical study of success factors of women entrepreneurs in southern region in Malaysia. International Journal of Economics and Finance, 3(2), 166-175.

Alene, E. T. (2020). Determinants that influence the performance of women entrepreneurs in micro and small enterprises in Ethiopia. Journal of Innovation and Entrepreneurship 9(24). https://doi.org/10.1186/s13731-020-00132-6

Aliyu, R. M., Ahmad, T. S. B. T., Nordin, N. B., \& Abdullahi, I. M. (2019). Innovation as a mediator on the assessment of market orientation, training, social network, access to finance and women business performance in the North-Western Nigeria: A proposed framework. International Journal of Academic Research in Business and Social Sciences, 9(1), 367-378. 
Kumaran Kanapathipillai, Subaneeswasri Narayanan, Sharvena Kumaran

ARE WOMEN ENTREPRENEURS' BUSINESS PERFORMANCES INFLUENCED BY

FINANCIAL RESOURCES? EMPOWERING WOMEN ENTREPRENEURS IN MALAYSIA

THROUGH FINANCIAL RESOURCES POST-COVID-19 PANDEMIC

Al-Shami, S. S. A., Muhamad, M. R., Majid, I., \& Rashid, N. (2019). Women entrepreneurs' micro and small business performance: insights from Malaysian microcredit. Intern. Journal of Entrepreneurship Small Business 38, 312-338.

Alturki, N. \& Braswell, R. (2010). Business women in Saudi Arabia: Characteristics, challenges, and aspirations in a regional context. Monitor Group, Retrieved from: www.monitor.com.

Aspray, W., \& McGrath Cohoon, M. J. (2007). Access to financial capital: A review of the research literature on women's entrepreneurship in the information technology field. Entrepreneurial Report Series, 3, National Center for Women \& Information Technology. Retrieved from: https://www.kauffman.org/wp-content/uploads.

Azam, S. M. F. \& Moha A. A., (2015). Differential roles between owner and manager in financial practice that contributes to business success: An analysis on Malaysian Small Business, Academic Journal of Interdisciplinary Studies, 4 (1 S2), 123-134

Bardasi, E., Sabarwal, S. \& Terrell, K., (2011). How do female entrepreneurs perform? Evidence from three developing regions, Small Business Economics, 37(4), 417-441.

Bartik, A. W., Bertrand, M., Cullen, Z., Glaeser, E. L., Luca, M. \& Stanton, C. (2020). The impact of COVID-19 on small business outcomes and expectations. Proceedings of the National Academy of Sciences, 117(30), 17656-17666.

Beck, T., \& Demirgü-Kunt, A. (2006). Small and medium-size enterprises: Access to finance as a growth constraint. Journal of Banking and Finance. 30(11).

Bhide, A. V. (1992). Bootstrap finance: The art of start-ups. Harvard Business Review. 70, 109-117.

Bouzekraoui, H., \& Ferhane, D. (2017). An exploratory study of women's entrepreneurship in Morocco. Journal of Entrepreneurship: Research and Practice, 2017 2-15.

Brixiova, Z., \& Kangoye, T. (2016). Start-up capital and women's entrepreneurship: evidence from Swaziland, IZA Discussion paper No.10279, October 2016, African Development Bank, 9-11.

Brown, L. D., \& Caylor, M. L. (2009). Corporate governance and firm operating performance. Review of Quantitative Finance and Accounting, 32(2),129-144. doi:10.1007/s11156-007-0082-3

Brush, C. G. (1992). Research on women business owners: past trends, a new perspective and future directions. Entrepreneurship: Theory and Practice, 16(4), 5-30.

Bygrave, W. D. (2003). Financing entrepreneurs and their businesses. Working Paper Presented at the First Annual Global Entrepreneurship Symposium, United Nations.

Cardella, G. M., Hernández S. B., \& Sanchez, J. (2020). Women entrepreneurship: A systematic review to outline the boundaries of scientific literature. Frontiers in Psychology. 11. 10.3389/fpsyg.2020.01557.

Carter, S. \& Anderson, S. (2001). On the move: Women and men business owners in the United Kingdom. Washington D.C: NFWBO and IBM, 4-6. 
Kumaran Kanapathipillai, Subaneeswasri Narayanan, Sharvena Kumaran

ARE WOMEN ENTREPRENEURS' BUSINESS PERFORMANCES INFLUENCED BY

FINANCIAL RESOURCES? EMPOWERING WOMEN ENTREPRENEURS IN MALAYSIA

THROUGH FINANCIAL RESOURCES POST-COVID-19 PANDEMIC

Carter, S., Anderson, S. \& Shaw, E. (2001). Women's business ownership: A review of the academic, popular and internet literature. Report to the Small Business Service, University of Strathclyde, Glasgow.

Carter, S., Rosa, P., \& Hamilton, D. (1996). Gender as a determinant of small business performance: Insights from a British study. Small Business Economics, 8(6), 463-478.

Carter, S., Wilson, F., Shaw, E. \& Lam, W. (2006). Gender, entrepreneurship and business finance: Investigating the relationship between banks and entrepreneurs in the UK. In Growth-oriented Women Entrepreneurs and their Businesses: A Global Research Perspective. Cheltenham, UK: Edward Elgar Publishing, 373-391.

Chaganti, R. (1986). Management in women-owned enterprises. Journal of Small Business Management, 24(4), 19-29.

Chipfunde, D., Siti Norbaya Yahya, \& Norfaridatul Akmaliah Othman (2021). The determinants, influencing the performance of women entrepreneurs in Malaysia: A conceptual framework. Estudios de Economia Aplicada, 39(4), 1-13.

Chinna, K., \& Choo, W. Y. (2015). Statistical Analysis Using SPSS. Pearson Malaysia, $2^{\text {nd }}$ ed. $43-146$.

Cohen, J. (1988). Statistical Power Analysis for the Behavioural Sciences. (2nd Ed.), Hillsdale, NJ: Lawrence Erlbaum

Cohoon, M., Wadhwa, V. \& Mitchell, L. (2010). The anatomy of an entrepreneur are successful women entrepreneurs different from men? Kauffman the Foundation of Entrepreneurship, Ewing Marion Kauffman Foundation, Kansas City, MO.

Cole, Rebel A. \& Wolken, John D. (1995). Financial Services Used by Small Businesses: Evidence from the 1993 National Survey of Small Business Finances. Federal Reserve Bulletin (July), 629-667.

Coleman, S. (2002). Constraints faced by women small business owners: evidence from the data. Journal of Developmental Entrepreneurship, 7(2), 151-175.

Coleman, S., \& Carsky, M. (1996). Financing small business: strategies employed by women entrepreneurs. The Journal of Applied Management and Entrepreneurship, 3(1), 28-42

Cooper, A. C., Gimeno-Gascon, J. \& Woo, C. Y. (1994). Initial human and financial capital as predictors of new venture performance. Journal of Business Venturing, 9, 371 395.

Cooper, A. C. (1971). The founding of technology based firms. Milwaukee, WI: Centre for Venture Management CVM.

Cooper, A. C., \& Gimeno-Gascon, F. J. (1992). Entrepreneurs, processes of founding, and new firm performance. In D. Sexton and J. Kasarda, eds., The State of the Art in Entrepreneurship. Boston, MA: PWS Kent Publishing Co.

Danga, M., Chongela, J., \& Kaudunde, I. (2019). Factors affecting the performance of rural small and medium enterprises (SMEs) a case study of Tanzania. International Journal of Academic Accounting, Finance \& Management Research, 3(5), 35-47.

Department of Statistics Malaysia (DOSM). (2021). Key Statistics of Labour Force in Malaysia. Retrieved from: http://dosm.gov.my. 
Kumaran Kanapathipillai, Subaneeswasri Narayanan, Sharvena Kumaran

ARE WOMEN ENTREPRENEURS' BUSINESS PERFORMANCES INFLUENCED BY

FINANCIAL RESOURCES? EMPOWERING WOMEN ENTREPRENEURS IN MALAYSIA

THROUGH FINANCIAL RESOURCES POST-COVID-19 PANDEMIC

Dharmaratne, K. L. B. G. (2012). Impact of individual factors on the business performance of women entrepreneurs in Sri Lanka. Sabaragamuwa University Journal, 11(1):139-165.

Dy, A., \& Jayawarna, D. (2020). Bios, mythoi and women entrepreneurs: A Wynterian analysis of the intersectional impacts of the COVID-19 pandemic on self-employed women and women-owned businesses. International Small Business Journal, 38(5), 391-403.

Dzisi, S., Meyer, D., Buckley, P., Selvarajah, C. (2015). The success of Ghanian women entrepreneurs: human and cash capital factors, Doctoral Study, Faculty of Business and Enterprise, Swinburne University of Technology, Melbourne, Victoria. 2 - 13.

Elahi, N. \& Malik, Q. A. (2021). Assessing the environmental and social obstacles to women entrepreneurs: a case study of Pakistan. Women Empowerment and Well-Being for Inclusive Economic Growth. IGI Global, PA, 90-105.

Eniola, A. A., \& Entebang, H. (2017). SME managers and financial literacy. Global Business Review, 18(3),1-18. doi:10.1177/0972150917692063

Eniola, A. A., \& Dada, D. A. (2018). The performance of women entrepreneurs: Human and financial capital. Triple A Research Journal of Social Science and Humanity, 2(1), 31-36.

Eniola, A. A., \& Entebang, H. (2015). Government Policy and Performance of Small and Medium Business Management. Int. J. Acad. Res. Bus. Soc. Sci. 5(2), 237248.

Freel, M., \& Carter, S., Tagg, S., \& Mason, C. (2012). The latent demand for bank debt: Characterizing "discouraged borrowers". Small Business Economics, 38. 399-418. 10.1007/s11187-010-9283-6.

Gundry, L. K. \& Welsch, H. P. (2001). The ambitious entrepreneur: high growth strategies of women-owned enterprises. Journal of Business Venturing, 16 (5), 453-470.

Gutierrez, P. I. R, Fuentes, M. D. M., \& Ariza, L. R., (2013). Women entrepreneurship in Mexico: an analysis of financial, human and social capital, European Scientific Journal, 9(16), 248-260.

Guzman, J., \& Kacperczyk, A. O. (2019). Gender gap in entrepreneurship. Res. Policy 48, 1666-1680. doi: 10.1016/j.respol.2019.03.012

Hansen, B., \& Hamilton, R. T. (2011). Factors distinguishing small firm growers and nongrowers. International Small Business Journal 29(3): 278-294.

Hart, S. \& Denison, D. R. (1987). Creating new technology-based organisations: a system dynamics model. Policy Studies Review, 6(3), 512 - 528.

Hassan, K. \& Yusof, R. (2015). Women in Economic and Social Transformation Era: Issue and Challenges. UUM Press.

Haynes, G. W., \& Haynes, D. C. (1999). The debt structure of small business owned by women in 1987 and 1993. Journal of Small Business Management 37(2), 1-19.

Hechevarría, D., Bullough, A., Brush, C., \& Edelman, L. (2019). High-growth women's entrepreneurship: fueling social and economic development. Journal of Small Business Management. 57, 5-13. doi: 10.1111/jsbm.12503 
Kumaran Kanapathipillai, Subaneeswasri Narayanan, Sharvena Kumaran

ARE WOMEN ENTREPRENEURS' BUSINESS PERFORMANCES INFLUENCED BY

FINANCIAL RESOURCES? EMPOWERING WOMEN ENTREPRENEURS IN MALAYSIA

THROUGH FINANCIAL RESOURCES POST-COVID-19 PANDEMIC

Henry, C. (2020). Women enterprise policy and COVID-19: Towards a gender sensitive response. Retrieved from https://sites.telfer.uottawa.ca/were/files/2020.

Hisrich, R. D. \& Brush, C. G., (1984). The women entrepreneur: management skills and business problems. Journal of Small Business Management, 22(1), 30 - 38.

HKMA, (2000), Hong Kong Monetary Authority, Surveys on the Financing Situation of Small and Medium-Sized Enterprises, Press Release, 23 June 2000, Retrieved from: http://www.hkma.gov.hk/eng/key-information/press-releases/2000.

Ibrahim, N., Mahmood, R., \& Bakar, M. (2016). Linking strategic improvisation and entrepreneurial self-efficacy to corporate entrepreneurship in Nigerian Higher Education Institutions (HEIs). Management Science Letters, 6(12), 742-752.

Kanapathipillai, K., \& Azam, S. M. F. (2019a). Women entrepreneurs path to success: An investigation of the critical success factors in Malaysia. European Journal of Human Resource Management Studies, 3(1): 106-121.

Kanapathipillai, K., \& Azam, S.M.F. (2019b). A conceptual understanding of the critical factors that induce women entrepreneurial success in the Klang Valley, Malaysia. European Journal of Management and Marketing Studies, 3(2): 105 - 120.

Kauffman, E. M. (2009), The Kauffman Firm Survey, Characteristics of New Firms: A Comparison by Gender, 12 - 13.

Kelly, D. J., Brush, C. G., Greene, P. G., \& Litovsky, Y. (2011). Women entrepreneurship worldwide. (Executive Report). Global Entrepreneurship Monitor (GEM).

Khaleque, A. (2018). Performance of women entrepreneurs: Does access to finance really matters. Eurasian Journal of Business and Economics, 11(21): 24-45.

Khursheed, A., Fatima, M., Mustafa, F. \& Nawaz, L. A. A. (2021). An empirical analysis of the factors influencing social entrepreneurship: a gendered approach. Management Letters/Cuadernos De Gestion, 21(2).

Krejcie, R. V., \& Morgan, D. W. (1970). Determining sample size for research activities. Educational \& Psychological Measurement.

Kuckertz, A., Brändle, L., Gaudig, A., Hinderer, S., Reyes, C. A. M., Prochotta, A., Steinbrink, K.M. \& Berger, E.S. (2020). Startups in times of crisis - a rapid response to the COVID-19 pandemic. Journal of Business Venturing Insights, 13, 1-13.

Kungwansupaphan, C \& Leihaothabam, J.K.S., (2016). Capital factors and rural women entrepreneurship development: A perspective of Manipur state, India. Gender in Management: An International Journal, 31(3), 207-221.

Kunkel, J. H., (1965). Values and Behaviour in Economic Development and Cultural Changes. 1, University of Chicago Press, p.153.

Lim, N. (2020). COVID-19 Implications for Contracts under Singapore and English Law. Sing. Comp. L. Rev., 119.

Mahat, N., Mahat, I. R. B., \& Mustafa, M. S. A. (2021). Covid -19 pandemic: issues and challenges among women entrepreneurs in Malaysia. International Journal of Academic Research in Business and Social Sciences, 11(6), 231-239. 
Kumaran Kanapathipillai, Subaneeswasri Narayanan, Sharvena Kumaran

ARE WOMEN ENTREPRENEURS' BUSINESS PERFORMANCES INFLUENCED BY

FINANCIAL RESOURCES? EMPOWERING WOMEN ENTREPRENEURS IN MALAYSIA

THROUGH FINANCIAL RESOURCES POST-COVID-19 PANDEMIC

Memon, A. (2020). Analyzing the entrepreneurial ecosystem for women entrepreneurs: a study of rural Jamshoro, Pakistan. Indian Journal of Commerce and Management Studies, 11(3), 45-59.

Muhammad, F., Bano, K., Muhammad, K. \& Baig, T. (2020). Women empowerment in Pakistan: assessing the socio-economic determinants. Studies of Applied Economics, 39(3).

Murphy, G. B., Trailer, J. W., \& Hill, R. C. (1996). Measuring performance in entrepreneurship research. Entrepreneurship and New Firm Development, 36(1), 1523. doi:10.1016/0148-2963(95)00159-x

Mustafa, F. Khursheed, A. Fatima, M. \& Rao, M. (2021). Exploring the impact of COVID-19 pandemic on women entrepreneurs in Pakistan. International Journal of Gender and Entrepreneurship, 13(2), 187-203. https://doi.org/10.1108/IJGE-09-20200149.

Nasri, N., \& Muhammad, S. (2018). Factors affecting female entrepreneurial intentions in Kabul, Afghanistan. Journal of Economics and Management Sciences, 1(1), 7-16.

National Foundation of Women Business Owners (2001). Entrepreneurial Vision in Action: Exploring Growth Among Women and Men-Owned Firms Washington, DC. NFWBO.

Orser, B. J., Allan, L. R., \& Manley, K. (2006). Women entrepreneurs and financial capital, Entrepreneurship Theory and Practice, 30, 643-665.

Orser, B. (2020). Women enterprise policy and COVID-19: Towards a gender sensitive response. Retrieved from https://sites.telfer.uottawa.ca/were/files/2020/06.

Papaneek, G. F., \& Harnis, J. R. (1980). Pakistan's development-social goals and private incentives. Harvard University Press, Cambridge, Massachusetts quoted Sharma, R.A.,op.cit., 6

Pelger, I., \& Tchouvakhina, M. (2013). Low debt entrepreneurs: in financing matters, women entrepreneurs play it safe, focus on economics, KFW Economic Research, 26, 2-3.

Pennisi, E. (2012). Understanding entrepreneurship in developing countries. Global Edge Business Review, Michigan State University.

Rao, S. (2014). Nurturing Entrepreneurial women. Journal of Entrepreneurship in Emerging Economies, 6(3), $268-297$.

Rashid, S., \& Ratten, V. (2020). A systematic literature review on women entrepreneurship in emerging economies while reflecting specifically on SAARC countries. Entrepreneurship and Organizational Change, Springer, Switzerland, 3788.

Rees, C., \& Miazhevich, G. (2005). The emerging identity of women managers in postSoviet Belarus. Women In Management Review, 20. 412-428. 10.1108/09649420510616809.

Robb, A. M., \& Coleman, S. (2010). Financing strategies of new technology-based firms: a comparison of women-and men-owned firms. Journal of Technology Management $\mathcal{E}$ Innovation, 5(2), 30-35. 
Kumaran Kanapathipillai, Subaneeswasri Narayanan, Sharvena Kumaran

ARE WOMEN ENTREPRENEURS' BUSINESS PERFORMANCES INFLUENCED BY

FINANCIAL RESOURCES? EMPOWERING WOMEN ENTREPRENEURS IN MALAYSIA

THROUGH FINANCIAL RESOURCES POST-COVID-19 PANDEMIC

Roper, S., \& Scott, J. M. (2009). Perceived financial barriers and the start-up decision: An econometric analysis of gender differences using GEM data. International Small Business Journal, 27, 149-171.

Salzman, H., McKernan, A. M., Pindus, N., \& Castaneda, R. M. (2006). Capital access for women, profile and analysis of u.s. best practice programs. Ewing Marion Kauffman Foundation Survey, $4-87$.

Scott, A. (2006). Entrepreneurship, innovation and industrial development: Geography and the creative field revisited. Small Business Economics. 26, 1-24. 10.1007/s11187004-6493-9.

Selvadurai, S. (2019). Why businesses run by women often fail. Daily Express, Mar 2019. Retrieved from http://www.dailyexpress.com.my/news/132151/why-businessesrun-by-women-often-fail.

Seetharaman, P. (2020). Business models shifts: impact of Covid-19. International Journal of Information Management, 54, 1-4.

Shaw, E., Carter, S., \& Brierton, J. (2001). Unequal entrepreneurs: Why female entrepreneurship is an uphill struggle. The Industrial Society Policy Report.

Shepherd, D. A. (2020). COVID 19 and entrepreneurship: time to pivot? Journal of Management Studies, 57(8), 1750-1753.

Sitharam, S., \& Hoque, M. (2016). Factors affecting the performance of small and medium enterprises in KwaZulu-Natal, South Africa. Journal of Problems and Perspectives in Management, 14(2), 203-212.

Srinivasan, R., Woo, C. Y., \& Cooper, A. C. (1994). Performance determinants for male and female entrepreneurs. West Lafayette, Ind:: Krannert Graduate School of Management, Institute for Research in the Behavioral, Economic, and Management Sciences.

Statistics on Women, Family and Community Malaysia, (2019), Ministry of Women, Family and Community Development.

Storey, D. J. (1994). Understanding the small business sector. London/New York: Routledge. Syed Z. A., \& Afida M. M. A. (2015). Strengthening access to finance for women-owned SMEs in developing countries, Equality, Diversity and Inclusion: An International Journal, 34(7)634 639.

Teoh, W. M. Y., \& Chong, S. C. (2007), Women entrepreneurship in Malaysia: a framework of factors influencing performance. Proceedings of the seventh Asian Academy of Management Conference 2007: Reimagining management in an era of multiple crisis: Success and sustainability of business in dynamic Asia, May 21 - 25, 2007.

Terziovski, M., \& Samson, D. (2000). The effect of company size on the relationship between TQM strategy and organisational performance. The TQM Magazine, 12(2): 144-149. doi:10.1108/09544780010318406

Thuaibah@Suaibah, A. B., Azlah, M. A., Rozeyta, O., Hishamuddin, M. S., \& Syaharizatul Noorizwan, M. (2007). Penglibatan kaum wanita dalam aktiviti keusahawanan di Negeri Johor: Kajian terhadap faktor-faktor kritikal kejayaan (Women's involvement in 
Kumaran Kanapathipillai, Subaneeswasri Narayanan, Sharvena Kumaran

ARE WOMEN ENTREPRENEURS' BUSINESS PERFORMANCES INFLUENCED BY

FINANCIAL RESOURCES? EMPOWERING WOMEN ENTREPRENEURS IN MALAYSIA

THROUGH FINANCIAL RESOURCES POST-COVID-19 PANDEMIC

entrepreneurship in Johor: A study about critical factors in achievement and failure in handling business. (PhD. Thesis), 181-184.

Udriyah, U., Tham, J. \& Azam, S. M. F. (2019). The Effects of Market Orientation and Innovation on Competitive Advantage and Business Performance of Textile SMEs, Management Science Letters, 9 (9), 1419-1428.

Ufuk, H., \& Ozgen, O. (2001). The profile of women entrepreneurs: A sample from Turkey. International Journal of Consumer Studies, 25 (4): 300-307.

Vann, V. D. (2011). A Study of Female Entrepreneurs Seeking Capital for Start-up Business, School of Business, Paper 3, $114-130$.

Verheul, I., \& Thurik, A. R. (2001). Start-up capital: does gender matter? Small Business Economics, 16(4), 329-345.

Vinesh, L. (2014). Role of women entrepreneurs in India. Global Journal of Financial Management, 6(5): 473-480.

Wang, S. S., Goh, J. R., Sornette, D., Wang, H., \& Yang, E. Y. (2020). Government support for SMEs in response to COVID-19: Theoretical Model Using Wang Transform (No. 20-59). Swiss Finance Institute

Watts, R. L. (2003). Conservatism in accounting part i: explanations and implications. Accounting Horizons, 17(3): 207-221. doi:10.2308/acch.2003.17.3.207

Welsh, D. H. B., Kaciak, E., \& Shamah, R. (2018). Determinants of women entrepreneurs' firm performance in a hostile environment. Journal of Business Research, 8(8), 481491.

Werner, A. (2020). Why unemployment fueled by pandemic is hitting women harder than men. CBSNEWSCOM. Retrieved from: https://www.cbsnews.com/news.

Wiklund, J., Patzett, H., \& Shepherd, A. D. (2009). Building an integrative model of small business growth, Small Business Economics, 32, 300-374.

Yusrinadini Z. Y., Maliani M., \& Nur Yuhainis Ab Wahab (2019). The influence of general self-efficacy on women entrepreneurs. Academy of Entrepreneurship Journal, 25(2): $1-4$.

Zeb, A. (2018). Determinants of successful women entrepreneurship in Pakistan. Abasyn Journal of Social Sciences, 2(11), 62-86.

Zhang, X., Xu, H., \& Zhang, Q. (2016). Research on financing of female entrepreneurs: Based on regional differences. Economists, 4, 14-15.

Zimmer, C., \& Alrich, H. (1987). Resource mobilization through ethnic networks: kinship and friendship, ties of shopkeepers in England. Sociological Perspective, 30(4), 422 455. 
Kumaran Kanapathipillai, Subaneeswasri Narayanan, Sharvena Kumaran

ARE WOMEN ENTREPRENEURS' BUSINESS PERFORMANCES INFLUENCED BY

FINANCIAL RESOURCES? EMPOWERING WOMEN ENTREPRENEURS IN MALAYSIA THROUGH FINANCIAL RESOURCES POST-COVID-19 PANDEMIC

Creative Commons licensing terms

Authors will retain copyright to their published articles agreeing that a Creative Commons Attribution 4.0 International License (CC BY 4.0) terms will be applied to their work. Under the terms of this license, no permission is required from the author(s) or publisher for members of the community to copy, distribute, transmit or adapt the article content, providing a proper, prominent and unambiguous attribution to the authors in a manner that makes clear that the materials are being reused under permission of a Creative Commons License. Views, opinions and conclusions expressed in this research article are views, opinions and conclusions of the author(s). Open Access Publishing Group and European Journal of Management and Marketing Studies shall not be responsible or answerable for any loss, damage or liability caused in relation to/arising out of conflict of interests, copyright violations and inappropriate or inaccurate use of any kind content related or integrated on the research work. All the published works are meeting the Open Access Publishing requirements and can be freely accessed, shared, modified, distributed and used in educational, commercial and non-commercial purposes under a Creative Commons Attribution 4.0 International License (CC BY 4.0) 